Article

\title{
Effect of Microalgae Incorporation on Quality Characteristics and Functional and Antioxidant Capacities of Ready-to-Eat Fish Burgers Made from Common Carp (Cyprinus carpio)
}

\author{
Ali Ben Atitallah ${ }^{1}$, Faiez Hentati ${ }^{1,2}$, Mouna Dammak ${ }^{1}$, Bilel Hadrich ${ }^{1}\left(\mathbb{D}\right.$, Imen Fendri ${ }^{3}$, \\ Mohamed-Ali Ayadi ${ }^{4}$, Philippe Michaud ${ }^{2}$ (D), Slim Abdelkafi ${ }^{1, *}$ and Mohamed Barkallah ${ }^{1}$ \\ 1 Unité de Biotechnologie des Algues, Biological Engineering Department, National Engineering School of \\ Sfax, University of Sfax, 3038 Sfax, Tunisia; atitali@yahoo.fr (A.B.A.); faizhentati@gmail.com (F.H.); \\ dammakmouna23@yahoo.fr (M.D.); bilelhadrich@yahoo.fr (B.H.); mohamedbarkallah@gmail.com (M.B.) \\ 2 Université Clermont Auvergne, CNRS, Institut Pascal, Polytech Clermont Ferrand, 2 avenue Blaise Pascal, \\ 63178 Aubière, France; philippe.michaud@uca.fr \\ 3 Laboratory of Plant Biotechnology Applied to the Improvement of Cultures, Faculty of Sciences of Sfax, \\ University of Sfax, 3029 Sfax, Tunisia; imen.fendri@fss.usf.tn \\ 4 Laboratory of Analysis Valorization and Food Safety, National Engineering School of Sfax, University of Sfax, \\ 3038 Sfax, Tunisia; ayadimedali@gmail.com \\ * Correspondence: slim.abdelkafi@enis.tn; Tel.: +216-97-458-923
}

Received: 4 April 2019; Accepted: 24 April 2019; Published: 2 May 2019

check for updates

\begin{abstract}
Microalgae have been used as natural ingredients to produce functional and nutritional food products. The impact of the addition of Chlorella minutissima, Isochrysis galbana, and Picochlorum sp. at concentrations of $0.5,1$, and $1.5 \% w / v$ on the texture and sensory attributes of canned burgers were investigated. The results show that carp formulations containing 1\% microalgae show significantly better classification performance for many textural and sensory parameters compared to the rest of the formulations. Also, these treatments had higher swelling ability as well as water and oil holding capacities, thanks to the important dietary fiber and polysaccharide contents found in microalgae. Moreover, microalgae-supplemented burgers were characterized as having low $a^{*}$ and $b^{*}$ values, which made the color appear to be pale orange. Additionally, thanks to its richness in pigments and polysaccharides, microalgae considerably ameliorated the antioxidant activities of the new prepared fish burgers. Thus, microalgae could be used as natural and nutritious ingredient to develop new fish-based products.
\end{abstract}

Keywords: burger fortification; microalgae; texture; polysaccharides; antioxidant activities

\section{Introduction}

Fishing in Tunisia has mainly exploited benthic stocks, which are currently in an optimum exploitation state or even overexploitated. This state has prompted the Tunisian authorities to seek effective solutions such as the development of aquaculture and the recovery of fish populations not exploited. As a result, the idea of exploiting freshwater fish species (Nile tilapia, common carp (Cyprinus Carpio) and common barbel (Barbus barbus)) in intensive farming has appeared. These freshwater fishes, which have a relatively low commercial value, bear the advantage of having a high nutritional quality. The common carp is a species of freshwater fish that belongs to the family of Cyprinidae [1]. The flesh of common carp is characterized by a beneficial nutritional composition of essential amino acids and a high content of omega-3 polyunsaturated fatty acids (eicosapentaenoic acid (20:5 n-3, 
EPA) and docosahexaenoic (22:6 n-3, DHA)) [2]. The presence of intramuscular bones in the flesh of common carp is the cause for its low level of consumption by Tunisians. Hence, it is very important to create and develop new fish-based products from these underused fish species so as to enhance their consumer acceptability.

In the agri-food industries, several synthetic additives have been used for the sake of coloring, flavoring, fortifying, and extending the shelf-life of commercialized products [3]. Still, many recent studies have indicated that the unreasonable consumption of synthetic food supplements is related to many health problems $[4,5]$. Thus, the need to use natural food fortifiers has pushed experts to prepare additives from natural resources that might be suitable in the production of fish products [3].

Microalgae have been exploited worldwide, with the principal genera used for functional and nutritional food being Arthrospira, Isochrysis, Picochlorum, and Chlorella [6-8]. These microalgae are rich in polyunsaturated fatty acids, phytosterols, heat-induced proteins, phenolic compounds, pigments, and sulfated polysaccharides $[9,10]$. Polysaccharides isolated from these microalgae have significant antioxidant properties in vitro and have effective scavenging abilities on superoxide radicals, hydroxyl radicals and hydroxyl peroxide. In addition, it is worth highlighting the significant quantity of fibers that microalgae supply [11]. The bioactive compounds present in microalgae have also been proven to show antibacterial and antifungal activities against some human pathogens [9]. The principal objectives of this study are first to produce new ready-to-eat fish burgers from common carp fortified with microalgae rich in bioactive compounds and second, to evaluate the microalgae's effects on the functional, physicochemical, textural, and microbiological characteristics of these products.

\section{Material and Methods}

\subsection{Microalgae}

The three species of microalgae (Chlorella minutissima, Isochrysis galbana, Picochlorum sp.) used in this study were obtained from the pilot unit of fish processing at Tabarka (Governorate of Jendouba, Tunisia) in collaboration with the Interprofessional Grouping of Fishery Products (GIPP, Tunis, Tunisia), which is an interprofessional organization in charge of the regulation of the market, improvement of quality, and promotion of exports in the aquaculture and fisheries sector in Tunisia. Microalgae were photoautotrophically cultivated in $250 \mathrm{~mL}$ flasks containing $100 \mathrm{~mL}$ sterilized culture $\mathrm{f} / 2$ medium containing $75 \mathrm{mg} / \mathrm{L} \mathrm{NaNO} 3,5 \mathrm{mg} / \mathrm{L} \mathrm{NaH} \mathrm{PO}_{4} \cdot 2 \mathrm{H}_{2} \mathrm{O}, 30 \mathrm{mg} / \mathrm{L} \mathrm{Na} 2 \mathrm{SiO}_{3} \cdot 9 \mathrm{H}_{2} \mathrm{O}, 1 \mathrm{~mL}$ of stock trace metal solution/L $\left(1 \mathrm{~mL} 3.15 \mathrm{~g} / \mathrm{L} \mathrm{FeCl}_{3} \cdot 6 \mathrm{H}_{2} \mathrm{O}, 4.36 \mathrm{~g} \mathrm{Na}_{2}\right.$ EDTA.2 $\mathrm{H}_{2} \mathrm{O}, 1 \mathrm{~mL} 9.8 \mathrm{~g} / \mathrm{L} \mathrm{CuSO} \cdot 5 \mathrm{H}_{2} \mathrm{O}, 1 \mathrm{~mL} 6.3 \mathrm{~g} / \mathrm{L}$ $\mathrm{Na}_{2} \mathrm{MoO}_{4} \cdot 2 \mathrm{H}_{2} \mathrm{O}, 1 \mathrm{~mL} 22 \mathrm{~g} / \mathrm{L} \mathrm{ZnSO}{ }_{4} \cdot 7 \mathrm{H}_{2} \mathrm{O}, 1 \mathrm{~mL} 10 \mathrm{~g} / \mathrm{L} \mathrm{CoCl}_{2} \cdot 6 \mathrm{H}_{2} \mathrm{O}$, and $1 \mathrm{~mL} 180 \mathrm{~g} / \mathrm{L} \mathrm{MnCl} 2 \cdot 4 \mathrm{H}_{2} \mathrm{O}$ ), and $0.5 \mathrm{~mL}$ of stock vitamin solution/L ( $1 \mathrm{~mL} 0.2 \mathrm{~g} / \mathrm{L}$ thiamine $\mathrm{HCl}$ (vitamin $\left.\mathrm{B}_{1}\right), 1 \mathrm{~mL} 1 \mathrm{~g} / \mathrm{L}$ biotin (vitamin $B_{8}$ ), and $1 \mathrm{~mL} 1 \mathrm{~g} / \mathrm{L}$ cyanocobalamin (vitamin $\left.B_{12}\right)$ ) in sea water $(30 \mathrm{~g} / \mathrm{L}$ salinity) (Guillard, 1975). The algal cells were incubated statically at $23^{\circ} \mathrm{C}$ and $\mathrm{pH} 7.8$ with continuous illumination using light-emitting diodes (LED) (maximum 4000 lux) (Fotosintetica \& Microbiologica Srl, Florence, Italy). The precultures were incubated for 8 days and then transferred as $10 \%$ of the starter into a $2 \mathrm{~L}$ flask containing $1.2 \mathrm{~L}$ sterilized culture $\mathrm{f} / 2$ medium using the same conditions to obtain a high biomass. Dense cell cultures were then inoculated using vertical LED-illuminated photobioreactors (Fotosintetica \& Microbiologica Srl) containing $40 \mathrm{~L}$ of $\mathrm{f} / 2$ medium with bubbling $\mathrm{CO}_{2}$-enriched air $\left(\mathrm{CO}_{2}\right.$ cylinder, Luxfer, Nottingham, UK) for 8 days.

\subsection{Catching Fish}

Common carp were caught in January 2017 from the Sidi Salem reservoir (Governorate of Beja, Tunisia) by professional fishermen using gill nets with a mesh size of $80 \mathrm{~mm}$. They were put in isotherm ice boxes $\left(\sim 0^{\circ} \mathrm{C}\right)$ and transferred after $1 \mathrm{~h}$ to the fish processing pilot unit of Tabarka (GIPP), where they were processed (washed, beheaded, gutted, and fileted). The skinless fish filets were then minced at $2000 \mathrm{rpm}$ for 2-3 $\mathrm{min}$ in a blender (Robot Coupe USA Inc., Ridgeland, MS, USA) and kept at $-20{ }^{\circ} \mathrm{C}$ for $48 \mathrm{~h}$. 


\subsection{Formulation and Production of Fish Burger}

Carp burgers were manufactured using a commercial burger maker (Model Hamburger MV NEW, Food Tech S.r.l., Bologna, Italy) after being thawed and chopped to a diameter of about $10 \mathrm{~mm}$, mixed with cornstarch $(1 \% w / v)$, salt $(2 \% w / v)$, and different concentrations $(0.5,1$ and $1.5 \%)$ of microalgae powders (Chlorella minutissima, Isochrysis galbana, Picochlorum sp.), and transformed into disc burgers that were $6 \mathrm{~cm}$ wide, $1.5 \mathrm{~cm}$ thick, and weighing $100 \mathrm{~g}$. The obtained burgers were soaked in sunflower oil $(20 \mathrm{~mL})$ and placed in RO-100 cans $(6.52 \mathrm{~cm}$ diameter, $3 \mathrm{~cm}$ height) using a seamer machine (Seamer Semiautomatica, MOD.AGM, S. Bologna, Italy). The canned burgers were then cooked at $120^{\circ} \mathrm{C}$ for $40 \mathrm{~min}$ using a retort. After cooling, the burgers were stored at $4{ }^{\circ} \mathrm{C}$ in a food refrigerator for further analysis (8 months). Algae-free burgers were used as controls.

\subsection{Physicochemical Properties of Fish Hamburger}

All physicochemical tests were done during the first month after production. A pH meter (Metrohm-744 pH meter, Switzerland) was calibrated using standard buffer solutions and was used to measure the $\mathrm{pH}$ of microalgae-fortified and unfortified fish burgers.

The water activity $\left(a_{w}\right)$ of burger samples was determined using SPRINT Novasina Thermoconstanter (TH-500, Switzerland) equipment at $25^{\circ} \mathrm{C}$. The equipment was previously calibrated according to the calibration procedure of the equipment manufacturer, using the following salts: $\mathrm{MgCl}_{2}$, $\mathrm{NaCl}, \mathrm{BaCl}_{2}$, and $\mathrm{K}_{2} \mathrm{Cr}_{2} \mathrm{O}_{7}$ (Sigma-Aldrich, St. Louis, MO, USA). All measurements were carried out in triplicate.

The infrared absorption spectra of all burger formulations were obtained using the Cary 630 FTIR spectrometer (Agilent Technologies., Santa Clara, CA, USA). The transmission spectra were obtained in the range of $600-4000 \mathrm{~cm}^{-1}$ at a resolution of $4 \mathrm{~cm}^{-1}$. An average of 10 scans was carried out for each sample to obtain a spectrum. All of the samples were tested in duplicate with plain $\mathrm{KBr}$ pellets as the blank. The acquisition and processing of spectra were carried out using the Agilent MicroLab PC software v.5.3 (Agilent Technologies Inc.).

Total solid (TS) content was determined after drying the samples in an air oven (Thermoline Scientific Equipment, Wetherill Park, Australia) at a temperature of $105^{\circ} \mathrm{C}$ to a point where the weight no longer changed. Dried burgers were fired in an electric furnace (Labec Laboratory Pty Ltd., Marrickville, NSW, Australia) at a high temperature of $550{ }^{\circ} \mathrm{C}$ to burn all organic matter and determine the mineral content. Total lipids were extracted using the modified procedure of Bligh and Dyer [12] and measured as described by Dammak et al. [13]. Briefly, lipids were obtained by using a hand-held homogenizer and extracted with a solvent mixture (chloroform-methanol-water; 2:1:1 $v / v)$ at a sample-to-solvent ratio of 1:3 (w/v). The lipid contents were determined gravimetrically after oven-drying $\left(80^{\circ} \mathrm{C}\right)$ the extract overnight. The protein content was fixed according to the classical Kjeldhal procedure with a nitrogen conversion factor of 6.25. Approximately $1 \mathrm{~g}$ of raw material was hydrolyzed with $15 \mathrm{~mL}$ concentrated sulfuric acid $\left(\mathrm{H}_{2} \mathrm{SO}_{4}\right)$ containing two copper catalyst tablets (Sigma-Aldrich) in a heat block (Kjeltec system 2020 digestor, Tecator Inc., Herndon, VA, USA) for $2 \mathrm{~h}$. After cooling, $\mathrm{H}_{2} \mathrm{O}$ was added to the hydrolysates before neutralization and titration. The determination of total dietary fiber in burger samples was done using the non-enzymatic gravimetric method (AOAC Official Method 993.21.) as described by Barkallah et al. [6]. Burger samples (0.5 g) were suspended in $5 \mathrm{~mL}$ of distilled water and incubated at $37^{\circ} \mathrm{C}$ for $90 \mathrm{~min}$ to solubilize sugars and other water-soluble components. Water-soluble fibers were then precipitated with $20 \mathrm{~mL}$ of $95 \%$ ethanol. Residue was washed sequentially with $4 \mathrm{~mL}$ of $78 \%$ ethanol, $2 \mathrm{~mL}$ of $95 \%$ ethanol, and $2 \mathrm{~mL}$ of acetone and then dried at $105^{\circ} \mathrm{C}$. The total dietary fiber content was calculated as the weight of residue minus the weights of protein and ash.

$$
\begin{gathered}
\text { Total dietary fiber }(\%)=100 \times\left(\left(\text { weight }_{\text {Residue }}-\left[\left(\text { weight }_{\text {Proteins }}+\text { weight }_{\text {Ash }}\right) / 100\right] \times\right.\right. \\
\text { weight } \text { Residue }) \text { weight Sample })
\end{gathered}
$$


For the determination of chlorophylls and carotenoids, burger samples $(0.2 \mathrm{~g})$ were sonicated in $2 \mathrm{~mL}$ of $95 \%$ ethanol at $65{ }^{\circ} \mathrm{C}$ for $30 \mathrm{~min}$ using an ultrasonic bath (Bandelin Electronic, Berlin, Germany). After sonication, the solutions were centrifuged at $10,000 \times g$ for $5 \mathrm{~min}$ at $4{ }^{\circ} \mathrm{C}$. Chlorophyll and carotenoid content was estimated by measuring the supernatant absorbance (A) at 666, 653, and $470 \mathrm{~nm}$ and using the following equations [14,15];

$$
\begin{gathered}
{\left[\text { Chlorophyll a] }(\mathrm{mg} / \mathrm{L})=\left(15.65 \times \mathrm{A}_{666}\right)-\left(7.340 \times \mathrm{A}_{653}\right)\right.} \\
{\left[\text { Chlorophyll b] }(\mathrm{mg} / \mathrm{L})=\left(27.05 \times \mathrm{A}_{653}\right)-\left(11.21 \times \mathrm{A}_{666}\right)\right.} \\
\text { Total Chlorophylls }(\mathrm{mg} / \mathrm{L})=\text { Chlorophyll a }+ \text { Chlorophyll b } \\
\text { Carotenoids }(\mathrm{mg} / \mathrm{L})=\left(1000 \times \mathrm{A}_{470}-(2.860 \times[\text { Chlorophyll a }])-(85.9 \times[\text { Chlorophyll b] })) / 245\right.
\end{gathered}
$$

\subsection{Functional Properties of Fish Burger}

The method of Kuniak and Marcessault [16] was followed to determine the swelling capacity (SWC) of fish burgers. Approximately $200 \mathrm{mg}$ of the sample was weighed into a $50 \mathrm{~mL}$ graduated glass cylinder. After making up the volume to $50 \mathrm{~mL}$ with deionized water (EASY-pure UV), the mixtures were vigorously stirred, and the material was left overnight at room temperature to equilibrate. The SWC was expressed as $\mathrm{ml}$ of swollen sample/g dry weight (mL/g DW). All measurements were carried out in duplicate.

The method of Okezie and Bello [17] was used to determine the water holding capacity (WHC) of fish burgers. Twenty $\mathrm{mL}$ of deionized water (EASY-pure UV) was added to each centrifuged tube containing $200 \mathrm{mg}$ of burger sample. Then, the tubes were stirred and held at room temperature for $24 \mathrm{~h}$. After centrifuging at $14,000 \times g$ for $30 \mathrm{~min}$ at $20^{\circ} \mathrm{C}$, the supernatant was discarded. The sample was weighed immediately and the WHC of burger samples was expressed as g water/g DW. All analyses were done in duplicate.

The oil holding capacity $(\mathrm{OHC})$ of fish burgers was measured using the method of Wong and Cheung [18]. The burger sample (3 g) was mixed with $8 \mathrm{~mL}$ of sunflower oil (Ben Arous, Tunisia). Each sample was stirred and held at room temperature for $30 \mathrm{~min}$. After that, the mixture was centrifuged at $2500 \times g$ for $30 \mathrm{~min}$ at $4{ }^{\circ} \mathrm{C}$. The oil supernatant was then removed and measured. The OHC of burger samples was expressed as $g$ of oil held/g of sample $(g / g$ DW).

\subsection{Sensory Evaluation}

The attributes of fish burgers were evaluated by 20 female and 10 male panelists aged from 20 to 45 years. The tasting panel included researchers and employees in the fish processing pilot unit. Burger samples were distributed on white polystyrene plates and shown to the panelists with three digit codes in a random order. Experiments were done in a sensory evaluation room equipped with white light and controlled ventilation; water was served for the purpose of cleaning the mouth between samples. Panel members evaluated the burgers for taste, body and texture, color, appearance, and odor based on a traditional 5 -point hedonic scale $(1=$ dislike a lot, $2=$ dislike a little, $3=$ neither like nor dislike, $4=$ like and $5=$ like a lot) for each parameter. A score of 4 was considered the threshold for acceptance of the fish burger.

\subsection{Color Analysis}

The color evaluation of unfortified and microalgae-fortified fish burgers was measured using a colorimeter (Minolta CR-400, Konica Minolta, Osaka, Japan)). An average color value was calculated by taking measurements from different points of the same sample (two on the top and three on the bottom) and the $L^{*} a^{*} b^{*}$ color space values were noted. 
The $L^{*}$ value indicates lightness $(0=$ darkness, $100=$ lightness $)$, the $a^{*}$ value indicates redness $(+60=$ red,$-60=$ green $)$, and the $b^{*}$ value indicates yellowness $(+60=$ yellow, $-60=$ blue $)$ [19]. Hue $\left(\mathrm{H}^{*}\right)$ and chroma $\left(\mathrm{C}^{*}\right)$ were calculated as follows: $\mathrm{H}^{*}=\operatorname{arctg}\left(\mathrm{b}^{*} / \mathrm{a}^{*}\right)$ and $\mathrm{C}^{*}=\left(\mathrm{a}^{* 2}+\mathrm{b}^{* 2}\right)^{1 / 2}$.

\subsection{Instrumental Texture Analysis}

All instrumental texture analyses were carried out on five carp burger formulations stored for $24 \mathrm{~h}$ at $4{ }^{\circ} \mathrm{C}$ using a professional analyzer of texture with a blade probe (TA Plus, Lloyd Instruments, Bognor Regis, UK). Cylindrical samples were manually cut from fish burgers, with approximately $30 \mathrm{~mm}$ diameter and a height of $15 \mathrm{~mm}$, and compressed twice to $50 \%$ of their original height $(15 \mathrm{~mm})$ with a flat-end cylindrical probe (12 mm diameter) at a constant speed of $10 \mathrm{~mm} / \mathrm{s}$. The texture settings were as follows: pre-test speed: $1.5 \mathrm{~mm} / \mathrm{s}$; target mode distance: $10 \mathrm{~mm}$; trigger force: 5 gtrigger type: auto; data acquisition rate: 200 points/s. The texture parameters were determined as described by Bourne [20] and calculated from the resulting force-deformation curves.

\subsection{Antioxidant Properties Evaluation Using DPPH and Ferric ReducingAantioxidant Power (FRAP) Methods}

The antiradical activity was measured using the synthetic radical DPPH (1,1-diphenyl-2picrylhydrazyl) using the method of Bersuder et al. [21]. Approximately $10 \mathrm{mg}$ of sample was suspended in $0.5 \mathrm{~mL}$ of distilled water. After making up the volume to $1.2 \mathrm{~mL}$ with $0.5 \mathrm{~mL}$ of absolute ethanol and $0.2 \mathrm{~mL}$ of DPPH ( $50 \mu \mathrm{M}$ in ethanol), the mixture was incubated for $30 \mathrm{~min}$ in the dark at room temperature. The absorbance was measured at $517 \mathrm{~nm}$ using the T70 UV-visible spectrophotometer (PG Instruments Ltd., Beijing, China). The control was done in the same manner, except that distilled water was used instead of sample.

From the absorbance, \% inhibition or \% scavenging activity is calculated using the formula

$$
\mathrm{DPPH} \text { scavenging activity }=(\mathrm{OD} \text { control }-\mathrm{OD} \text { sample }) / \mathrm{OD} \text { control } \times 100
$$

The ferric reducing antioxidant power (FRAP) of burger samples was determined using the method of Yildirim et al. [22]. Fish burgers were cut into small pieces $(10 \mathrm{mg})$, immersed in $0.1 \mathrm{~mL}$ of distilled water, and mixed with $2.5 \mathrm{~mL}$ of sodium phosphate buffer $\left(\mathrm{NaHPO}_{4}, 0.2 \mathrm{M}, \mathrm{pH} 6.6\right)$ and $2.5 \mathrm{~mL}$ of potassium ferricyanide $\left(\mathrm{K}_{3} \mathrm{Fe}(\mathrm{CN})_{6}\right)(1 \% \mathrm{w} / \mathrm{v})$. The mixtures were incubated for $30 \mathrm{~min}$ at $50{ }^{\circ} \mathrm{C}$. After incubation, $2.5 \mathrm{~mL}$ of $10 \%$ trichloroacetic acid (TCA) was added and the reaction mixtures were centrifuged at $10,000 \times g$ for $10 \mathrm{~min}$ at $4{ }^{\circ} \mathrm{C}$. Finally, $2.5 \mathrm{~mL}$ of the upper layer solution was taken and mixed with $2.5 \mathrm{~mL}$ of distilled water and $0.5 \mathrm{~mL}$ of $0.1 \%$ ferric chloride. The procedure was carried out in triplicate, and absorbance was measured at $700 \mathrm{~nm}$. Increased concentrations of the extracts showed higher absorbance, which in turn indicates better reducing capacity.

\subsection{Microbiological Analyses}

The produced carp burgers were tested for the presence of common foodborne pathogens such as Escherichia coli, Salmonella spp., Listeria monocytogenes, Bacillus cereus, Staphylococcus aureus, and Campylobacter sp. All analyses were done according to standard methods for the examination of ready-to-eat food [23].

\subsection{Statistical Analysis}

The statistical comparisons were made at least in duplicate using the one-way ANOVA test followed by post hoc Duncan's Multiple Range Tests (DMRT) ( $p$ values $<0.05$ were considered to be statistically significant) and the obtained values were expressed as mean \pm standard deviation (SD). IBM SPM statistical software version 19 (IBM Corp., USA) was used to perform all statistical analyses. 


\section{Results and Discussion}

\subsection{Preliminary Results}

The sensory evaluations of individual fish burgers for taste, after-taste, odor, color, mouth texture, and overall acceptability are detailed in Table 1.

Table 1. Mean scores of tasting panelists $(n=32)$ for sensory properties of control and microalgae-fortified $(0.5,1$ and $1.5 \%)$ burgers after production.

\begin{tabular}{|c|c|c|c|c|c|}
\hline & Color & Odor & Taste & After-taste & Texture \\
\hline Control burger & $4.0 \pm 0.3$ & $4.0 \pm 0.3$ & $4.4 \pm 0.6$ & $4.3 \pm 0.2$ & $4.0 \pm 0.1$ \\
\hline $0.5 \%$ Isochrysis burger & $4.2 \pm 0.3^{a}$ & $4.0 \pm 0.3$ & $4.3 \pm 0.2$ & $4.4 \pm 0.3$ & $4.1 \pm 0.3$ \\
\hline $1 \%$ Isochrysis burger & $4.2 \pm 0.2^{\mathrm{a}}$ & $4.1 \pm 0.4$ & $4.6 \pm 0.2^{\mathrm{a}, \mathrm{e}}$ & $4.4 \pm 0.2$ & $4.2 \pm 0.1^{\mathrm{a}}$ \\
\hline $1.5 \%$ Isochrysis burger & $3.8 \pm 0.3^{\mathrm{a}, \mathrm{e}, \mathrm{g}}$ & $3.7 \pm 0.5^{\mathrm{b}, \mathrm{e}, \mathrm{g}}$ & $3.7 \pm 0.3^{\mathrm{c}, \mathrm{f}, \mathrm{h}}$ & $3.8 \pm 0.2^{\mathrm{c}, \mathrm{f}, \mathrm{h}}$ & $3.8 \pm 0.3^{\mathrm{a}, \mathrm{e}, \mathrm{g}}$ \\
\hline $0.5 \%$ Picochlorum burger & $4.3 \pm 0.2^{b}$ & $4.0 \pm 0.4$ & $4.4 \pm 0.3$ & $4.3 \pm 0.2$ & $4.2 \pm 0.2^{\mathrm{a}}$ \\
\hline $1 \%$ Picochlorum burger & $4.3 \pm 0.2^{b}$ & $4.0 \pm 0.3$ & $4.5 \pm 0.2$ & $4.4 \pm 0.2$ & $4.2 \pm 0.3^{\mathrm{a}}$ \\
\hline $1.5 \%$ Picochlorum burger & $4.0 \pm 0.2^{\mathrm{e}, \mathrm{g}}$ & $4.0 \pm 0.3$ & $3.8 \pm 0.3^{\mathrm{c}, \mathrm{f}, \mathrm{h}}$ & $4.0 \pm 0.3^{b, e, g}$ & $4.0 \pm 0.2^{\mathrm{d}, \mathrm{f}}$ \\
\hline $0.5 \%$ Chlorella burger & $4.3 \pm 0.2^{b}$ & $4.0 \pm 0.2$ & $4.7 \pm 0.3^{b}$ & $4.4 \pm 0.4$ & $4.2 \pm 0.3^{a}$ \\
\hline $1 \%$ Chlorella burger & $4.4 \pm 0.2^{c}$ & $4.0 \pm 0.5$ & $4.6 \pm 0.3^{a}$ & $4.3 \pm 0.3$ & $4.2 \pm 0.3^{\mathrm{a}}$ \\
\hline $1.5 \%$ Chlorella burger & $3.9 \pm 0.1^{\mathrm{e}, \mathrm{g}}$ & $3.5 \pm 0.4^{\mathrm{c}, \mathrm{f}, \mathrm{g}}$ & $3.9 \pm 0.3^{\mathrm{c}, \mathrm{f}, \mathrm{h}}$ & $3.9 \pm 0.3^{b, f, g}$ & $4.0 \pm 0.2^{\mathrm{d}, \mathrm{f}}$ \\
\hline
\end{tabular}

Control vs. fortified $\left(0.5,1\right.$, and 1.5\%) burgers: ${ }^{\mathrm{a}} p<0.05 ;{ }^{\mathrm{b}} p<0.01 ;{ }^{\mathrm{c}} p<0.001 .0 .5 \%$ microalgae burgers vs. 1 and $1.5 \%$ microalgae burgers: ${ }^{\mathrm{d}} p<0.05$; ${ }^{\mathrm{e}} p<0.01{ }^{\mathrm{f}} p<0.001$. $1 \%$ microalgae burgers vs. $1.5 \%$ microalgae burgers: ${ }^{\mathrm{f}} p<0.05 ;{ }^{\mathrm{g}} p<0.01{ }^{\mathrm{h}} p<0.001$.

The hedonic results showed the highest scores for carp burgers containing $0.5 \%$ and $1 \%$ of each microalga. Statistically, burger treatments with a higher microalgae concentration (1.5\%) had lower sensory acceptability for all the organoleptic characteristics compared to formulations with the lower microalgae concentrations $(p<0.05)$ (Table 1$)$. The inappropriate taste caused by the addition of $1.5 \%$ of Isochrysis galbana, Picochlorum sp., and Chlorella minutissima is related to the compounds obtained from lipid oxidation and to the minerals that not only act as pro-oxidant molecules but also might produce metallic off-flavors [24]. Yet, taste scores of carp burgers formulated with $0.5 \%$ and $1 \%$ microalgae were similar to the control fish burgers (Figure 1). The microalgae supplementation modified the conventional color of burgers to a darker one depending on microalgae content but not on microalgae species. Formulations with 1.5\% microalgae had the lowest color scores (Table 1). Thus, burgers supplemented with $0.5 \%$ and $1 \%$ of microalgae were selected for further analyses so as to evaluate their physicochemical properties.

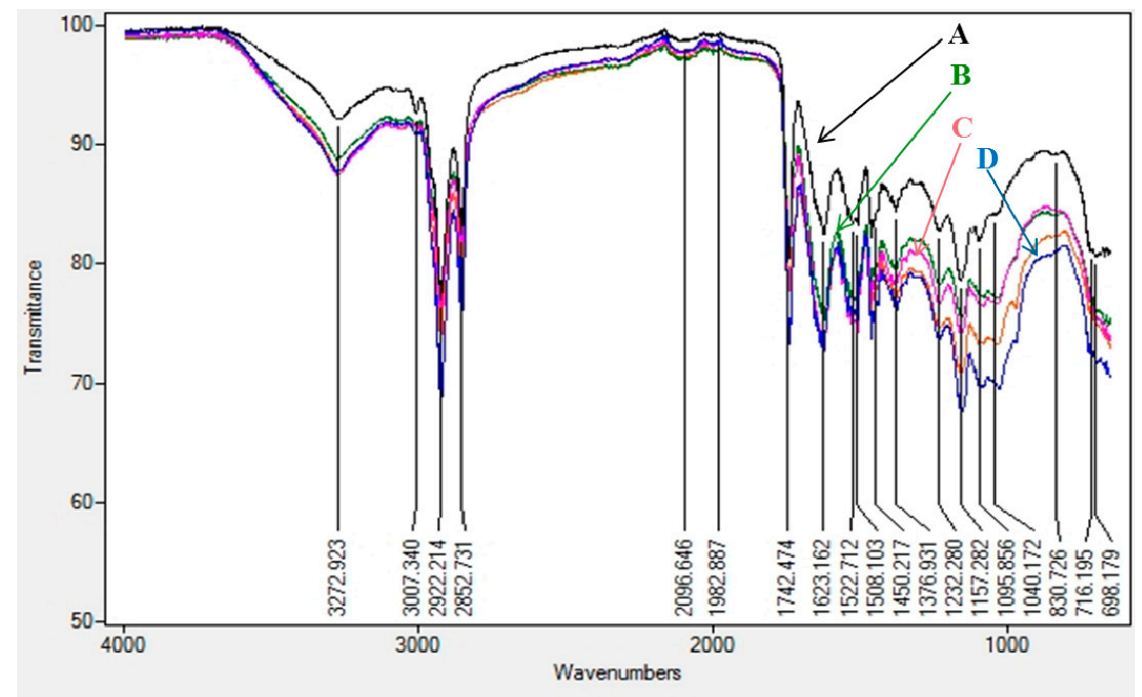

Figure 1. The infrared spectrum of (A): control burger, (B): $1 \%$ Picochlorum burger, (C): $1 \%$ Isochrysis burger and (D): $1 \%$ Chlorella burger. 
The incorporation of microalgae into the burger composition had no effect on $\mathrm{pH}$ values (Table 2), something necessary for a better stability of fish products. Besides, there were no significant differences in fat and protein content between control and microalgae-fortified samples $(p>0.05)$ (Table 2).

Table 2. Mean values for physicochemical characteristics of control and microalgae-fortified burgers at one week after production.

\begin{tabular}{cccccccc}
\hline & $\begin{array}{c}\text { Control } \\
\text { Burger }\end{array}$ & $\begin{array}{c}\mathbf{0 . 5 \%} \\
\text { Isochrysis } \\
\text { Burger }\end{array}$ & $\begin{array}{c}\mathbf{1 \%} \\
\text { Isochrysis } \\
\text { Burger }\end{array}$ & $\begin{array}{c}\mathbf{0 . 5 \%} \\
\text { Picochlorum } \\
\text { Burger }\end{array}$ & $\begin{array}{c}\mathbf{1 \%} \\
\text { Picochlorum } \\
\text { Burger }\end{array}$ & $\begin{array}{c}\mathbf{0 . 5 \%} \\
\text { Chlorella } \\
\text { Burger }\end{array}$ & $\begin{array}{c}\mathbf{1 \%} \\
\text { Chlorella } \\
\text { Burger }\end{array}$ \\
\hline pH & $7.21 \pm 0.07$ & $7.175 \pm 0.005$ & $7.17 \pm 0.01$ & $7.185 \pm 0.005$ & $7.17 \pm 0.01$ & $7.17 \pm 0.01$ & $7.16 \pm 0.001$ \\
Water activity (aw) & $0.982 \pm 0.00$ & $0.981 \pm 0.001$ & $0.88 \pm 0.001^{\mathrm{a}}$ & $0.98 \pm 0.001$ & $0.971 \pm 0.000^{\mathrm{a}, \mathrm{d}}$ & $0.982 \pm 0.001$ & $0.972 \pm 0.001^{\mathrm{a}, \mathrm{d}}$ \\
Moisture (\% FW) & $77.03 \pm 0.055$ & $76.82 \pm 0.082^{\mathrm{a}}$ & $76.68 \pm 0.160^{\mathrm{b}, \mathrm{d}}$ & $76.7 \pm 0.3^{\mathrm{b}}$ & $76.65 \pm 0.03^{\mathrm{b}}$ & $76.75 \pm 0.19^{\mathrm{a}}$ & $76.5 \pm 0.15^{\mathrm{b}, \mathrm{d}}$ \\
Total solids (\% FW) & $22.96 \pm 0.06$ & $23.18 \pm 0.08$ & $23.31 \pm 0.160^{\mathrm{a}}$ & $23.3 \pm 0.03^{\mathrm{a}}$ & $23.35 \pm 0.03^{\mathrm{a}}$ & $23.24 \pm 0.19$ & $23.5 \pm 0.145^{\mathrm{b}, \mathrm{d}}$ \\
Proteins (\% DW) & $79.66 \pm 0.12$ & $79.4 \pm 0.04$ & $79.15 \pm 0.05$ & $79.36 \pm 0.402$ & $79.5 \pm 0.355$ & $79.15 \pm 0.650$ & $79.02 \pm 0.555$ \\
$\quad$ Fats (\% DW) & $7.8 \pm 0.15$ & $7.71 \pm 0.1$ & $7.65 \pm 0.120$ & $7.65 \pm 0.225$ & $7.54 \pm 0.6^{\mathrm{a}}$ & $7.70 \pm 0.15$ & $7.64 \pm 0.1$ \\
Ash (\% DW) & $11.13 \pm 0.11$ & $11.29 \pm 0.06$ & $11.77 \pm 0.07^{\mathrm{c}, \mathrm{f}}$ & $11.33 \pm 0.02^{\mathrm{a}}$ & $11.9 \pm 0.101^{\mathrm{c}, \mathrm{f}}$ & $11.29 \pm 0.05$ & $11.49 \pm 0.03^{\mathrm{b}, \mathrm{d}}$ \\
Carbohydrates (\% DW) & $2.8 \pm 0.15$ & $2.8 \pm 0.12$ & $2.82 \pm 0.13$ & $2.8 \pm 0.1$ & $2.89 \pm 0.17$ & $2.81 \pm 0.2$ & $2.84 \pm 0.17$ \\
Total dietary fibers & $0.329 \pm 0.025$ & $0.375 \pm 0.06$ & $0.49 \pm 0.05^{\mathrm{b}, \mathrm{d}}$ & $0.474 \pm 0.07^{\mathrm{b}}$ & $0.86 \pm 0.12^{\mathrm{c}, \mathrm{f}}$ & $0.46 \pm 0.06^{\mathrm{b}}$ & $0.67 \pm 0.05^{\mathrm{c}, \mathrm{e}}$ \\
(g/100g DW) & & & & & & &
\end{tabular}

Control vs. fortified $(0.5,1$, and $1.5 \%)$ burgers: ${ }^{\mathrm{a}} p<0.05 ;{ }^{\mathrm{b}} p<0.01 ;{ }^{\mathrm{c}} p<0.001 .0 .5 \%$ microalgae burgers vs. 1 and $1.5 \%$ microalgae burgers: ${ }^{\mathrm{d}} p<0.05$; $^{\mathrm{e}} p<0.01$; ${ }^{\mathrm{f}} p<0.001$. The percentage is calculated relative to a dry weight basis (DW) for proteins, fats, Ash, carbohydrates and total dietary fibers whereas the moisture content and total solids are expressed with respect to a fresh weight basis (FW).

These contents were confirmed qualitatively with Fourier-transform infrared spectroscopy FTIR analysis (Figure 1).

The strong absorption in the region of $3200 \mathrm{~cm}^{-1}$ corresponds to the hydroxyl $(\mathrm{O}-\mathrm{H})$ stretching vibration of proteins and residual water (Figure 1). The strong absorption in the region of $3000 \mathrm{~cm}^{-1}$ and $2800 \mathrm{~cm}^{-1}$ corresponds to the stretching of $\mathrm{NH}_{2}$ groups, which reflects the high protein content in burger samples (Figure 1). The protein spectrum was characterized by the presence of absorption peaks at 1624 and $1522 \mathrm{~cm}^{-1}$ attributed to the $\mathrm{NH}$ and $\mathrm{C}=\mathrm{O}$ groups of amides $\mathrm{I}\left(1590-1650 \mathrm{~cm}^{-1}\right)$ and the stretching of $\mathrm{NH}$ groups and asymmetric $\mathrm{N}=\mathrm{O}$ groups of amide $\mathrm{II}\left(1500-1560 \mathrm{~cm}^{-1}\right)$ [13]. The lipid spectrum was characterized by the presence of absorption peaks at 2922, 2852, and $1742 \mathrm{~cm}^{-1}$ attributed to the $\operatorname{Vas}\left(\mathrm{CH}_{2}\right), \mathrm{Vs}\left(\mathrm{CH}_{2}\right)$, and $\mathrm{V}(\mathrm{C}=\mathrm{O})$ stretching, respectively, while the absorption peak at $1377 \mathrm{~cm}^{-1}$ mainly showed the $\mathrm{C}-\mathrm{O}$ stretching vibrations of carboxylic acids [13]. The absorption peaks found between 950 and $1200 \mathrm{~cm}^{-1}$ showed carbohydrates (Figure 1). Compared to controls, microalgae-fortified samples did not show any specific absorption peaks. However, total solid (TS) contents were higher in burgers fortified with 1\% Chlorella minutissima, 1\% Isochrysis galbana, and 1\% Picochlorum sp. $(p<0.05)$ (Table 2). Similarly, total dietary fiber values were greater in the burgers fortified with $1 \%$ microalgae. This might be the result of the high dietary fiber content of microalgae (Table 2). The high dietary fiber content of fortified burgers probably had an important role in their lower water activity $\left(a_{\mathrm{w}}\right)$ [25]. This property serves to limit microbial growth and lipid oxidization and to optimize the physical characteristics of fish burgers. Similarly, the ash contents of the fortified burgers with $1 \%$ microalgae were significantly higher than those of the control burgers. These findings correspond to the results of other studies that indicate that these microalgae are rich in minerals $[11,26]$. According to the results, carp burgers supplemented with $1 \%$ microalgae were chosen as the best final fish products and selected for other analyses to evaluate their textural, functional, microbiological, and antioxidant properties.

\subsection{Textural Parameters}

The textural parameter values of fish burgers are shown in Table 3.

Compared to control carp burgers, the addition of 1\% Isochrysis galbana, 1\% Picochlorum sp., or 1\% Chlorella minutissima led to a significant increase in hardness. This could presumably be attributed to the compositional differences between control and microalgae-fortified burgers, resulting in different protein, fat, and water ratios, important elements in determining the final product consistency [27]. These results are in accordance with reports by Cofrades et al. [27] and Fernandez-Martin et al. [28] on 
burger patties with added seaweeds. Furthermore, fibers and polysaccharides of microalgae can play an important role in modifying the hardness of these processed products. Indeed, depending on the amount and type of fibers, varying results were reported regarding the hardness of food products. Thus, both hardening and softening have been observed when fibers were added to various cooked food products $[19,29]$.

Table 3. Parameters obtained by texture analyzer for control burgers and fortified burgers with $1 \%$ of microalgae.

\begin{tabular}{ccccc}
\hline & $\begin{array}{c}\text { Hardness } \\
\mathbf{( N )}\end{array}$ & $\begin{array}{c}\text { Springiness } \\
\mathbf{( c m )}\end{array}$ & $\begin{array}{c}\text { Chewiness } \\
\mathbf{( N \cdot c m )}\end{array}$ & Cohesiveness \\
\hline Control burger & 8.35 & 0.36 & 1.11 & 0.37 \\
$\mathbf{1 \%}$ Isochrysis burger & $10.03^{\mathrm{c}}$ & 0.33 & $1.36^{\mathrm{b}}$ & 0.33 \\
$\mathbf{1 \%}$ Picochlorum burger & $11.42^{\mathrm{c}}$ & 0.36 & $1.40^{\mathrm{b}}$ & 0.34 \\
$\mathbf{1 \%}$ Chlorella burger & $10.05^{\mathrm{c}}$ & 0.41 & $1.60^{\mathrm{c}}$ & 0.39 \\
\hline
\end{tabular}

Control vs. microalgae-fortified burgers: ${ }^{\mathrm{a}} p<0.05{ }^{\mathrm{b}} p<0.01{ }^{\mathrm{c}} p<0.001$.

In addition, chewiness reflected results pertaining to hardness, and these results were not surprising since chewiness is a secondary parameter that depends on hardness [30]. However, the addition of microalgae had no significant effect on the springiness and cohesiveness of carp burgers (Table 3). Cohesiveness results of carp burgers formulated with $1 \%$ of microalgae were comparable with the values reported by Kumarathunge et al. [31] for Catla burgers and formulated with $0.5 \%(w / w)$ Ulva lactuca.

\subsection{Functional Properties of Carp Burgers}

The functional characteristics of control and microalgae-fortified burgers are shown in Table 4 .

Table 4. Functional parameters of control and microalgae-fortified fish burgers.

\begin{tabular}{ccccc}
\hline & $\begin{array}{c}\text { Control } \\
\text { Burger }\end{array}$ & $\begin{array}{c}\mathbf{1 \%} \\
\text { Isochrysis } \\
\text { Burger }\end{array}$ & $\begin{array}{c}\mathbf{1 \%} \\
\text { Picochlorum } \\
\text { Burger }\end{array}$ & $\begin{array}{c}\mathbf{1 \%} \\
\text { Chlorella } \text { Burger }\end{array}$ \\
\hline $\begin{array}{c}\text { Swelling capacity (SWC) } \\
\text { (mL/g DW) * }\end{array}$ & $3.14 \pm 0.115$ & $3.59 \pm 0.116^{\mathrm{c}}$ & $3.54 \pm 0.1^{\mathrm{c}}$ & $3.52 \pm 0.002^{\mathrm{c}}$ \\
$\begin{array}{c}\text { Water holding capacity } \\
(\text { WHC) (g/g DW) }\end{array}$ & $2.31 \pm 0.135$ & $2.79 \pm 0.02^{\mathrm{c}}$ & $2.81 \pm 0.11^{\mathrm{c}}$ & $2.84 \pm 0.04^{\mathrm{c}}$ \\
$\begin{array}{c}\text { Oil holding capacity } \\
(\text { OHC) }(\mathrm{g} / \mathrm{g} \text { DW) }\end{array}$ & $0.85 \pm 0.07$ & $0.96 \pm 0.04^{\mathrm{a}}$ & $0.91 \pm 0.002^{\mathrm{a}}$ & $0.92 \pm 0.001^{\mathrm{a}}$ \\
\hline
\end{tabular}

${ }^{*}$ Results are expressed as means $\pm \mathrm{SD}(\mathrm{n}=3)$. Control burgers vs. microalgae-fortified burgers: ${ }^{\mathrm{a}} p<0.05 ;{ }^{\mathrm{b}} p<0.01$; ${ }^{c} p<0.001$.

Highly significant differences $(p<0.05)$ were observed in WHC between the control $(2.31 \mathrm{~g} / \mathrm{g}$ DW) and the $1 \%$ Isochrysis-, $1 \%$ Picochlorum-, and 1\% Chlorella-fortified burgers $(2.79,2.81$, and $2.84 \mathrm{~g} / \mathrm{g}$ DW, respectively) (Table 4). The greater WHC of the three microalgae burgers suggests that they could be used as functional natural ingredients in food treatments to modify viscosity and texture, reduce dehydration during storage, and minimize the energetic value of food products. Compared to control burgers, important differences $(p<0.05)$ were observed in terms of the oil holding capacities (OHC) displayed by the three microalgae (Table 4). This reached $0.96 \mathrm{~g} / \mathrm{g}, 0.91 \mathrm{~g} / \mathrm{g}$, and $0.92 \mathrm{~g} / \mathrm{g}$ for Isochrysis galbana, Picochlorum sp., and Chlorella minutissima treatments, respectively (Table 3). These $\mathrm{OHC}$ values could be of a particular interest, especially for the binding of fat during industrial food processing and storage. This might be attributed to the high water and oil binding capacities of the three microalgae fibers [19,32]. In addition, the control burgers showed the lowest values of swelling capacity $(3.14 \mathrm{~mL} / \mathrm{g})$. The highest values of swelling capacity were obtained by Isochrysis $(3.59 \mathrm{~mL} / \mathrm{g}$ 
DW) and Picochlorum (3.54 mL/g DW) burgers and by Chlorella burgers $(3.52 \mathrm{~mL} / \mathrm{g} \mathrm{DW})(p<0.001)$ (Table 4). Furthermore, the difference between the functional capacities of the three microalgae could be explained by the differences in their proportion, composition and characteristics of dietary fibers [19]. These results are in accordance with previous reports $[28,33]$.

\subsection{Microbiological Quality of Carp Burgers}

No mold, Enterobacteriaceae, yeast, coliform bacteria, or foodborne pathogens (Salmonella spp., Shigella spp., Listeria monocytogenes, Bacillus cereus, and Campylobacter spp.) were detected in any of the burgers during two months of storage at $4^{\circ} \mathrm{C}$. These microbiological results suggest that the production of the carp burgers was carried out with good hygienic and sanitary practices.

\subsection{Color Measurement of Burger Samples}

The $L^{*}$ attributes show that control burgers had higher lightness values $(46.75 \pm 0.335)$ than fortified burgers with $1 \%$ Isochrysis galbana $(41.1 \pm 0.95), 1 \%$ Picochlorum sp. $(41.26 \pm 0.9)$, and $1 \%$ Chlorella minutissima $(43.7 \pm 0.7)(p<0.001)$. This due to the darker colors obtained from microalgae (Table 5).

Table 5. Color analysis of control burgers and microalgae-fortified burgers.

\begin{tabular}{lcccc}
\hline & $\begin{array}{l}\text { Control } \\
\text { Burger }\end{array}$ & $\begin{array}{l}\mathbf{1 \%} \\
\text { Isochrysis } \\
\text { Burger }\end{array}$ & $\begin{array}{l}\mathbf{1 \%} \\
\text { Picochlorum } \\
\text { Burger }\end{array}$ & $\begin{array}{l}\mathbf{1 \%} \\
\text { Chlorella } \text { Burger }\end{array}$ \\
\hline $\mathbf{L}^{*}$ & $46.75 \pm 0.335$ & $41.1 \pm 0.95^{\mathrm{a}}$ & $41.26 \pm 0.9^{\mathrm{a}}$ & $43.7 \pm 0.7^{\mathrm{a}}$ \\
$\mathbf{a}^{*}$ & $10.65 \pm 0.22$ & $4.22 \pm 0.135^{\mathrm{a}}$ & $4.93 \pm 0.05^{\mathrm{a}}$ & $4.71 \pm 0.03^{\mathrm{a}}$ \\
$\mathbf{b}^{*}$ & $11.4 \pm 0.71$ & $9.55 \pm 0.3^{\mathrm{a}}$ & $8.48 \pm 0.55^{\mathrm{a}}$ & $7.88 \pm 0.48^{\mathrm{a}}$ \\
${\text { Chroma }\left(\mathbf{C}^{*}\right)}^{\text {Hue }\left(\mathbf{H}^{*}\right)}$ & $15.6 \pm 0.3$ & $10.4 \pm 0.1^{\mathrm{a}}$ & $9.8 \pm 0.2^{\mathrm{a}}$ & $9.18 \pm 0.2^{\mathrm{a}}$ \\
\hline
\end{tabular}

Control burgers vs. microalgae-fortified burgers: ${ }^{\mathrm{a}} p<0.001$.

Accordingly, this could presumably be attributed to the differences in composition resulting from different amounts of pigments (carotenoids, chlorophylls, and phycocyanin) and water, which is a determining element in the final color product [19]. This finding indicates that the tested natural colorants in this study have no tendency to lighten the burger's color during the storage period. Indeed, these results are in accordance with previous reports [34]. Compared to controls, burger samples prepared with microalgae were characterized by low $\mathrm{a}^{*}$ and $\mathrm{b}^{*}$ positive values $(p<0.05)$, leading to orange hues $\left(60-66^{\circ}\right)$. This makes the color shift from light to pale orange (Table 5). This color change was confirmed by the chroma values, which decreased significantly by the addition of microalgae $(p<0.001)$ (Table 5). This can be explained by the richness of green microalgae in carotenoids. Thus, these data can be used to predict the effects of microalgae pigment addition on the conventional colors of products in which they are used. The green microalgae pigments could also be useful as natural colorants in fish products.

\subsection{Antioxidant Properties of Fish Burgers}

Thanks to their safety and efficiency, much recent interest has been paid to the considerable role of fortified foods with bioactive substances usually derived from plants and microalgae in the cure of many human disorders. In order to estimate the effect of the three microalgae on the burgers' antioxidant capacities, two different methods were used: the DPPH free radical scavenging assay and the ferric reducing antioxidant power (FRAP) assay (Table 6). 
Table 6. Pigments content and antioxidant activities of control and microalgae-fortified burgers after production.

\begin{tabular}{ccccc}
\hline & $\begin{array}{c}\text { Control } \\
\text { Burger }\end{array}$ & $\begin{array}{c}\text { 1\% Isochrysis } \\
\text { Burger }\end{array}$ & $\begin{array}{c}\text { 1\% Picochlorum } \\
\text { Burger }\end{array}$ & $\begin{array}{c}\text { 1\% Chlorella } \\
\text { Burger }\end{array}$ \\
\hline Chlorophylls (mg/100g DW) & 0 & $23.28 \pm 1.97^{\mathrm{a}}$ & $26.52 \pm 2.7^{\mathrm{a}}$ & $23.14 \pm 1.25^{\mathrm{a}}$ \\
Phycocyanin (mg/100g DW) & 0 & $0.45 \pm 0.07^{\mathrm{a}}$ & $0.47 \pm 0.02^{\mathrm{a}}$ & $0.45 \pm 0.08^{\mathrm{a}}$ \\
Carotenoids (mg/100g DW) & 0 & $12.5 \pm 1.47^{\mathrm{a}}$ & $11.43 \pm 0.77^{\mathrm{a}}$ & $10.31 \pm 0.8^{\mathrm{a}}$ \\
Scavenging activity (\%) $^{*}$ & 56.28 & $65.61^{\mathrm{a}}$ & $83.81^{\mathrm{a}}$ & $95.23^{\mathrm{a}}$ \\
Reducing power * & 0.35 & $0.75^{\mathrm{a}}$ & $0.46^{\mathrm{a}}$ & $0.50^{\mathrm{a}}$ \\
\hline
\end{tabular}

Control burgers vs. microalgae-fortified burgers: ${ }^{a} p<0.001$. ${ }^{*}$ The scavenging activity of DPPH free radicals (\%) and the reducing power (absorbance at $700 \mathrm{~nm}$ ) were determined at a sample concentration of $10 \mathrm{mg} / \mathrm{mL}$.

The chlorophyll, carotenoid, and phycocyanin contents of burgers were also measured (Table 6). Compared to the control treatment, results show that treatments containing $1 \%$ Chlorella minutissima, $1 \%$ Isochrysis galbana, and 1\% Picochlorum sp. significantly increased the levels of chlorophylls $(p<0.001)$, carotenoids $(p<0.001)$, and phycocyanin $(p<0.001)$ (Table 6$)$. In addition, they enhanced the scavenging $(p<0.001)$ and reducing power $(p<0.001)$ activities (Table 6$)$. In a sample concentration of $10 \mathrm{mg} / \mathrm{mL}$, carp burgers containing 1\% Chlorella minutissima, $1 \%$ Picochlorum sp., and 1\% Isochrysis galbana had considerably higher DPPH scavenging activities $(95.2 \%, 83.8 \%$, and $65.6 \%$, respectively) than control burgers $(56.2 \%)(p<0.001)$ (Table 6). Furthermore, a comparable tendency was also noticed for the FRAP method. At a sample concentration of $10 \mathrm{mg} / \mathrm{mL}$, the ferric reducing activities of unfortified and fortified carp burgers with $1 \%$ Chlorella minutissima, $1 \%$ Isochrysis galbana, and $1 \%$ Picochlorum sp. were equal to $0.35,0.5,0.75$, and $0.46(p<0.001)$, respectively, (Table 6). Similar previous studies have postulated that the antioxidant activity of food products was increased by the presence of algae. In a comparative study, Jónsdóttir et al. [35] noted the high antioxidant activity from seafood products containing Fucus vesiculosus powder (brown algae). The rise in scavenging of free radicals could be attributed to an increase in pigment [32] and polysaccharide [36,37] content, which plays an important role in the protection of the body's cells and molecules from oxidative stress and in cancer chemoprevention. For example, Chlorella species are known to contain several types of polysaccharides, including $\beta$-1,3-glucan, an active free-radical scavenger [38]. In addition, many previous studies found that Isochrysis galbana was rich in polysaccharides, with content up to $25 \%$ (dry cell weight) [36]. These polysaccharides were shown to have high scavenging activities against superoxide and hydroxyl radicals as well as moderate reductive power in a concentration-dependent manner [36]. Generally, these results indicate that fish burger transformation did not have a negative effect on the efficiency of the antioxidant components.

\section{Conclusions}

Besides their role as nutritional components, microalgae serve as a good source of natural flavoring and coloring agents. Furthermore, microalgae rich in polysaccharides play a crucial role in the textural maintenance of final fish products by improving their functional properties (water and oil holding capacities). The addition of microalgae significantly ameliorated the physicochemical composition and the sensory acceptability of the final fish product and conserved its microbiological quality. These microalgae treatments improved not only the nutritional content of the prepared fish products but also raised their antioxidant action. Therefore, the evaluated microalgae might be an effective alternative to fortification with synthetic chemical supplements, which can cause undesirable effects on consumers.

Author Contributions: A.B.A., F.H. and M.D. carried out the production of fish burgers and their analysis. B.H. carried out the statistical analysis. A.B.A., I.F., S.A. and M.B. participated in the design of the study. A.B.A., I.F., M.-A.A., P.M., S.A. and M.B. conceived the study, and participated in its design and coordination and helped to draft the manuscript. All authors read and approved the final manuscript.

Funding: This study was supported by the Tunisian Ministry of Higher Education and Scientific Research. The funders had no role in the study design, data collection and analysis, decision to publish, and preparation of the manuscript. 
Conflicts of Interest: The authors confirm that they have no conflicts of interest with respect to the study described in this manuscript.

\section{References}

1. Maiditsch, I.P.; Ladich, F. Effects of Temperature on Auditory Sensitivity in Eurythermal Fishes: Common Carp Cyprinus carpio (Family Cyprinidae) versus Wels Catfish Silurus glanis (Family Siluridae). PLoS ONE 2014, 9, e108583. [CrossRef] [PubMed]

2. Ljubojevic, D.; Trbovic, D.; Lujic, J.; Bjelic-Cabrilo, O.; Kostic, D.; Novakov, N.; Cirkovic, M. Fatty acid composition of fishes from inland waters. Bulg. J. Agric. Sci. 2013, 19, 62-74.

3. Cedola, A.; Cardinali, A.; Nobile, M.A.D.; Conte, A. Fish burger enriched by olive oil industrial by-Product. Int. J. Food Sci. Nutr. 2017, 5, 837-844. [CrossRef] [PubMed]

4. Abdelkafi, S.; Labat, M.; Ben Ali Gam, Z.; Lorquin, J.; Sayadi, S. Optimized conditions for the synthesis of vanillic acid under hypersaline conditions by Halomonas elongata DSM $2581^{\mathrm{T}}$ resting cells. World J. Microbiol. Biotechnol. 2008, 24, 675-680. [CrossRef]

5. Carocho, M.; Barreiro, M.F.; Morales, P.; Ferreira, I.C.F.R. Adding molecules to food, pros and cons: A review on synthetic and natural food additives. Compr. Rev. Food Sci. Food Saf. 2014, 13, 377-399. [CrossRef]

6. Barkallah, M.; Dammak, M.; Louati, I.; Hentati, F.; Hadrich, B.; Mechichi, T.; Ayadi, M.A.; Fendri, I.; Attia, H.; Abdelkafi, S. Effect of Spirulina platensis fortification on physicochemical, textural, antioxidant and sensory properties of yogurt during fermentation and storage. LWT-Food Sci. Technol. 2017, 84, 323-330. [CrossRef]

7. Alavi, N.; Golmakani, M.T. Improving oxidative stability of virgin olive oil by addition of microalga Chlorella vulgaris biomass. J. Food Sci. Technol. JFST 2017, 54, 2464-2473. [CrossRef]

8. Ben Amor, F.; Elleuch, F.; Ben Hlima, H.; Garnier, M.; Saint-Jean, B.; Barkallah, M.; Pichon, C.; Abdelkafi, S.; Fendri, I. Proteomic analysis of the Chlorophyta Dunaliella new strain AL-1 revealed global changes of metabolism during high carotenoid production. Mar. Drugs 2017, 15, 293. [CrossRef]

9. Wells, M.L.; Potin, P.; Craigie, J.S.; Raven, J.A.; Merchant, S.S.; Helliwell, K.E.; Smith, A.G.; Camire, M.E.; Brawley, S.H. Algae as nutritional and functional food sources: Revisiting our understanding. J. Appl. Phycol. 2017, 29, 949-982. [CrossRef]

10. Hadrich, B.; Akremi, I.; Dammak, M.; Barkallah, M.; Fendri, I.; Abdelkafi, S. Optimization of lipids' ultrasonic extraction and production from Chlorella sp. using response-surface methodology. Lipids Health Dis. 2018, 17, 87. [CrossRef]

11. Matos, Â.P.; Feller, R.; Moecke, E.H.S.; Oliveira, J.V.; Junior, A.F.; Derner, R.B.; Santanna, E.S. Chemical characterization of six microalgae with potential utility for food application. J. Am. Oil Chem. Soc. 2016, 93, 963-972. [CrossRef]

12. Bligh, E.G.; Dyer, W.J. A rapid method of total lipid extraction and purification. Can. J. Biochem. Physiol. 1959, 37, 911-917. [CrossRef] [PubMed]

13. Dammak, M.; Hadrich, B.; Miladi, R.; Barkallah, M.; Hentati, F.; Hachicha, R.; Laroche, C.; Michaud, P.; Fendri, I.; Abdelkafi, S. Effects of nutritional conditions on growth and biochemical composition of Tetraselmis sp. Lipids Health Dis. 2017, 16, 41. [CrossRef] [PubMed]

14. Lichtenthaler, H.K.; Wellburn, A.R. Determination of total carotenoids and chlorophylls A and B or leaf in dissolved solvents. Biochem. Soc. Trans. 1985, 11, 591-592. [CrossRef]

15. Kumar, P.; Ramakritinan, C.M.; Kumaraguru, A.K. Solvent extraction and spectrophotometric determination of pigments of some algal species from the shore of puthumadam, southeast coast of India. Int. J. Oceans Oceanogr. 2010, 4, 29-34.

16. Kuniak, L.; Marchessault, R.H. Study of the Crosslinking Reaction between Epichlorohydrin and Starch. Starch-Starke 1972, 24, 110-116. [CrossRef]

17. Okezie, B.O.; Bello, A.B. Physicochemical and functional properties of winged bean flour and isolate compared with soy isolate. J. Food Sci. 1988, 53, 450-454. [CrossRef]

18. Wong, K.H.; Cheung, P.C.K. Nutritional evaluation of some subtropical red and green seaweeds. Part I-Proximate composition, amino acid profiles and some physicochemical properties. Food Chem. 2000, 71, 475-482. [CrossRef]

19. Huber, E.; Francio, D.L.; Biasi, V.; Mezzomo, N.; Ferreira, S.R.S. Characterization of vegetable fiber and its use in chicken burger formulation. J. Food Sci. Technol. 2016, 53, 3043-3052. [CrossRef] 
20. Bourne, M.C. Texture profile analysis. Food Technol. 1978, 32, 62-66.

21. Bersuder, P.; Hole, M.; Smith, G. Antioxidants from a heated histidine glucose model system I: Investigation of the antioxidant role of histidine and isolation of antioxidants by high performance liquid chromatography. J. Am. Oil Chem. Soc. 1998, 75, 181-187. [CrossRef]

22. Yildirim, A.; Mavi, A.; Kara, A.A. Determination of antioxidant and antimicrobial activities of Rumex crispus L. Extracts. J. Agric. Food Chem. 2001, 49, 4083-4089. [CrossRef] [PubMed]

23. APHA. Compendium of Methods for the Microbiological Examination of Foods, 4th ed.; Downes, F.P., Ito, K., Eds.; American Public Health Association (APHA): Washington, DC, USA, 2001.

24. Shimamatsu, H. Mass production of Spirulina, an edible microalga. Hydrobiologia 2004, 512, 39-44. [CrossRef]

25. Selani, M.M.; Shirado, G.A.N.; Margiotta, G.B.; Saldaña, E.; Spada, F.P.; Piedade, S.M.S.; Contreras-Castillo, C.J.; Canniatti-Brazaca, S.G. Effects of pineapple byproduct and canola oil as fat replacers on physicochemical and sensory qualities of low-fat beef burger. Meat Sci. 2016, 112, 69-76. [CrossRef]

26. Tokuşoglu, O.; üUnal, M.K. Biomass Nutrient Profiles of Three Microalgae: Spirulina platensis, Chlorella vulgaris, and Isochrisis galbana. Food Sci. 2006, 68, 1144-1148. [CrossRef]

27. Cofrades, S.; López-López, I.; Solas, M.; Bravo, L.; Jiménez-Colmenero, F. Influence of different types and proportions of added edible seaweeds on characteristics of different types and proportions of added edible seaweeds on characteristics of low-salt gel/emulsion meat systems. Meat Sci. 2008, 79, 767-776. [CrossRef]

28. Fernandez-Martin, F.; Lopez-Lopez, I.; Cofrades, S.; Colmenero, F.J. Influence of adding Sea Spaghetti seaweed and replacing the animal fat with olive oil or a konjac gel on pork meat batter gelation. Potential protein/alginate association. Meat Sci. 2009, 83, 209-217. [CrossRef]

29. López-Vargas, J.H.; Fernández-López, J.; Pérez-Álvarez, J.Á.; Viuda-Martos, M. Quality characteristics of pork burger added with albedo-fiber powder obtained from yellow passion fruit (Passiflora edulis var. flavicarpa) co-products. Meat Sci. 2014, 97, 270-276. [CrossRef]

30. Ben Halima, N.; Borchani, M.; Fendri, I.; Khemakhem, B.; Gosset, D.; Baril, P.; Pichon, C.; Ayadi, M.-A.; Abdelkafi, S. Optimised amylases extraction from oat seeds and its impact on bread properties. Int. J. Biol. Macromol. 2015, 72, 1213-1221. [CrossRef]

31. Kumarathunge, N.C.; Jayasinghe, J.M.P.; Abeyrathne, E.D.N.S. Development of Sea Lettuce (Ulva lactuca) and Catla (Catla catla) Incorporated Protein and Fiber Rich Fish Burger. Int. J. Res. Agric. Sci. 2016, 4, 2348-3997.

32. Roohinejad, S.; Koubaa, M.; Barba, F.J.; Saljoughian, S.; Amid, M.; Greiner, R. Application of seaweeds to develop new food products with enhanced shelf-life, quality and health-related beneficial properties. Food Res. Int. 2016, 99, 1066-1083. [CrossRef] [PubMed]

33. Cox, S.; Abu-Ghannam, N. Enhancement of the phytochemical and fibre content of beef patties with Himanthalia elongata seaweed. Int. J. Food Sci. Technol. 2013, 48, 2239-2249.

34. Senthil, M.A.; Mamatha, B.; Mahadevaswamy, M. Effect of using seaweed (Eucheuma) powder on the quality of fish cutlet. Int. J. Food Sci. Nutr. 2005, 56, 327-335. [CrossRef] [PubMed]

35. Jónsdóttir, R.; Geirsdóttir, M.; Hamaguchi, P.Y.; Jamnik, P.; Kristinsson, H.G.; Undeland, I. The ability of in vitro antioxidant assays to predict the efficiency of a cod protein hydrolysate and brown seaweed extract to prevent oxidation in marine food model systems. J. Sci. Food Agric. 2015, 96, 2125-2135. [CrossRef] [PubMed]

36. Sun, Y.; Wang, H.; Guo, G.; Pu, Y.; Yan, B. The isolation and antioxidant activity of polysaccharides from the marine microalgae Isochrysis galbana. Carbohydr. Polym. 2014, 26, 22-31. [CrossRef]

37. Chen, Y.X.; Liu, X.Y.; Xiao, Z.; Huang, Y.F.; Liu, B. Antioxidant activities of polysaccharides obtained from Chlorella pyrenoidosa via different ethanol concentrations. Int. J. Biol. Macromol. 2016, 91, 505-509. [CrossRef] [PubMed]

38. Bari, E.; Arciola, C.R.; Vigani, B.; Crivelli, B.; Moro, P.; Marrubini, G.; Sorrenti, M.; Catenacci, L.; Bruni, G.; Chlapanidas, T.; et al. In Vitro effectiveness of microspheres based on silk sericin and Chlorella vulgaris or Arthrospira platensis for wound healing applications. Materials 2017, 10, 983. [CrossRef] [PubMed]

(C) 2019 by the authors. Licensee MDPI, Basel, Switzerland. This article is an open access article distributed under the terms and conditions of the Creative Commons Attribution (CC BY) license (http://creativecommons.org/licenses/by/4.0/). 